\title{
EFFECT OF CREST ELEVATIONS ON THE OVERTOPPING DISCHARGES OVER COMPOSITE SEAWALL
}

\author{
Burak Aydoğan ${ }^{1}$, Berna Ayat ${ }^{1}$, Yalçın Yüksel ${ }^{1}$, Esin Çevik ${ }^{1}$, and Özgen Göller ${ }^{1}$
}

\begin{abstract}
Overtopping discharges over a composite seawall model has been studied experimentally. Effect of crest elevations on the overtopping discharges was studied based on the new data set of 132 tests. Test data is compared to the existing formulas given by EurOtop Manual (2007) and EurOtop II Manual (2016). Results showed that both EurOtop Manual (2007) and EurOtop II (2016) formulas for composite seawalls are applicable to our test setup with a roughness coefficient of 0.55 which corresponds a rubble mound composite structure with two layers and an impermeable core. Vertical wall caused the composite structure act as an impermeable structure. Height of the storm wall was raised 2, 4, 6,8 , and $10 \mathrm{~cm}$ successively during the tests. Results showed that a reduction rate clearly depends on the wave steepness.
\end{abstract}

Keywords: composite seawall; wave overtopping; crest elevation.

\section{INTRODUCTION}

Seawalls are the most common type of coastal structures, which protects the coast against flooding and wave attack. Horizontal composite seawalls are generally used to reduce wave reflections of vertical seawalls. These structures may be built in areas where a stable coastline is desired together with low reflections on the seaside. Although there are many studies focused on overtopping discharges of different kind of structures there is still much to consider in terms of spatial distribution and performance of higher vertical wall sections with or without a parapet.

Overtopping discharge rate $\mathrm{q}\left(\mathrm{m}^{3} / \mathrm{s} / \mathrm{m}\right)$ is generally used as a design parameter to check if the overtopping values are within allowable limits (EurOtop Manual, 2007). Some important guidelines on wave overtopping are TAW (2002), EurOtop Manual (2007) and EurOtop II Manual (2016). These guidelines have taken into account a wide range of coastal structures and gave generalized equations for different types of structures. The data used in these guidelines included small-scale and large-scale experimental data from different laboratories (Van der Meer and Janssen, 1994). These data were evaluated together with field data collected from prototype scale structures by using numerical methods in CLASH Project (De Rouck et al., 2009). This allowed the evaluation of scale effects and complex structures. Another study based on data collected in CLASH project is an ANN model based on over 10000 data on many different geometries taking into account 31 geometric and hydraulic parameters (Van Gent et al., 2007; Verhaeghe et al., 2008). Van der Meer et al. (2014) revisited all the literature and the CLASH database and published some new physical insights and design formulas on wave overtopping for both sloping and vertical structures recently. Van Doorslaer et al. (2015) evaluated the effect of crest modifications as a measure to reduce overtopping of non-breaking waves over a smooth dike slope based on over 1000 scale model tests. The authors aimed at including the reductive effect of a storm wall or a berm in the design formulas. Recently EurOtop (2007) has been updated to a new version, EurOtop II (2016).

To decrease the overtopping rates a small structure which is called as a bullnose can be situated at the top of the vertical wall. EurOtop II (2016) mentions that the size of this structure is quite effective on the overtopping rates and the manual gives guidance for this kind of a structure based on existing guidance in the Netherlands and physical model studies. Reductive effect of a storm wall over a composite seawall on the wave overtopping has not been studied extensively.

Overtopping discharges over a composite seawall model has been studied in this study. Effect of crest elevations on the overtopping discharges over composite seawall was investigated experimentally based on the new data set of 132 tests. Test data is compared to the existing formulas.

\section{EXPERIMENTAL STUDY}

The experiments were carried out in the Coastal and Harbour Engineering Laboratory in Yildiz Technical University. The two-dimensional wave flume has a length of $26 \mathrm{~m}$, width of $1 \mathrm{~m}$, and a depth of $1 \mathrm{~m}$ was used. The flume is equipped with an irregular wave generator which has a capability

\footnotetext{
${ }^{1}$ Department of Civil Engineering, Yildiz Technical University, 34220, Esenler, İstanbul, Turkiye
} 
of active wave absorption and HR DAQ software for the data acquisition and analysis. A displacement piston type wave maker was used to generate waves. The wave maker measures the incoming wave and corrects the paddle motion to absorb it. The resultant wave field is totally predictable even with highly reflective models. HR DAQ is a spectral analysis program that produces the wave spectrum and associated spectral parameters.

The composite seawall model consisting three layer armored berm and a plain vertical wall made of plexiglas were located on a 1/10 sloping rigid bed. Facility setup for all tests is shown in Figure 1.

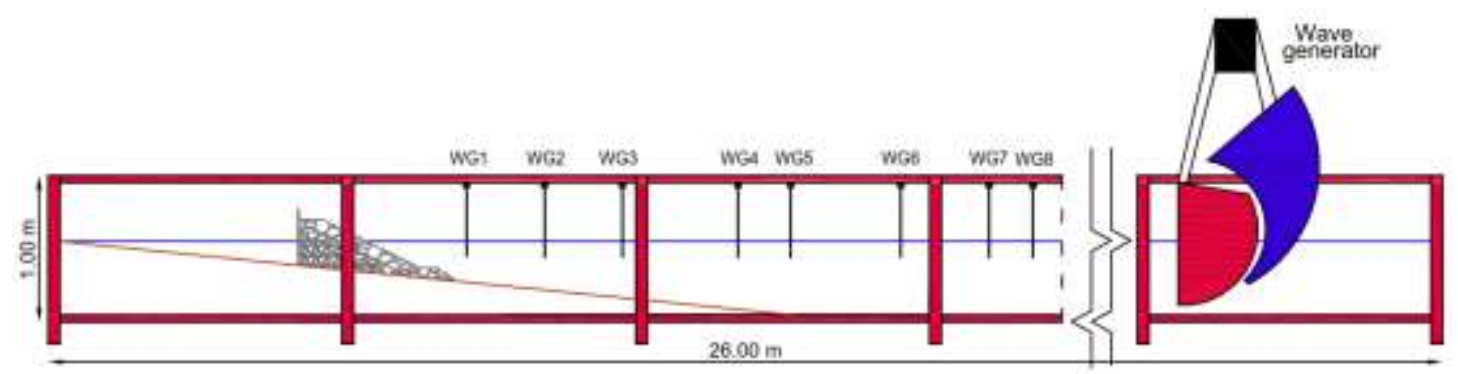

Figure 1 Test setup and the positions of the wave gauges in Yildiz Technical University wave flume.

The tests have been carried out for eight different irregular wave conditions. Wave characteristics are measured by using eight resistive type wave gauges. Locations of the wave gauges are shown in Figure 1. Four wave gauges (WG5, 6, 7, 8) in front of the wave generator have been used to separate incoming and reflected waves. One wave gauge (WG 4) is located at the toe of the structure in order to measure the wave characteristics at the toe of the structure. And the rest of the wave gauges (WG1, 2,3 ) are positioned over the $1 / 10$ sloping bed in front of the structure. For irregular waves the incident wave spectrum is the JONSWAP Spectrum with $\gamma=3.3$. The significant wave height was in between 5.8-15 cm and the wave period was in between 1.31-2.00 s. Perpendicular wave attack $\left(\gamma_{\beta}=1\right)$ was considered for all tests. All the waves can be considered as non-breaking waves since all breaking indices were above 2 . Water depth within the wave flume was between 52.5 and $65.5 \mathrm{~cm}$. The water depth at the toe of the rubble mound reclamation was between 29.5 and $42.5 \mathrm{~cm}$. Crest elevation of the vertical wall was raised $2 \mathrm{~cm}$ at a time up to $10 \mathrm{~cm}$. Overtopped waves are captured by a tank situated just behind the wall. Individual overtopping of single waves were not measured during the tests only the mean overtopping discharges are measured. Most of the tested wave train consist 500 to 1100 waves in order to have reliable overtopping discharges. About $5 \%$ of the tests had shorter run times with minimum 200 waves, which were related to the largest overtopping values in the test runs. Tests with $\mathrm{R}_{\mathrm{c}} / \mathrm{H}_{\mathrm{m} 0}$ values lower than 0.83 could not be completed because of excessive overtopping. Similarly tests with $\mathrm{R}_{\mathrm{c}} / \mathrm{H}_{\mathrm{m} 0}$ values greater than 2.92 could not be measured due to no measurable overtopping. Test wave trains consist of repetitions of a unique one minute wave series. Summary of the parameters and the ranges used during the experiments are shown in Table 1. All the dimensions and the material used to model the composite seawall and the photo taken from the model set-up are shown in Figure 2.

\begin{tabular}{|l|l|l|}
\hline \multicolumn{4}{|l|}{ Table 1 Characteristic parameters used in the tests. } \\
\hline Spectral wave height & $\mathrm{H}_{\mathrm{m} 0}(\mathrm{~cm})$ & $5.8-15$ \\
\hline Mean spectral wave period $(\mathrm{s})$ & $\mathrm{T}_{\mathrm{m}-1,0}(\mathrm{~s})$ & $1.31-2$ \\
\hline Water depth at the toe of the structure & $\mathrm{d}(\mathrm{cm})$ & $29.5-42.5$ \\
\hline Crest elevation & $\mathrm{R}_{\mathrm{c}}(\mathrm{cm})$ & $6.2-29.2$ \\
\hline Dimensionless crest elevation, & $\mathrm{R}_{\mathrm{c}} / \mathrm{H}_{\mathrm{m} 0}$ & $0.83-2.92$ \\
\hline
\end{tabular}




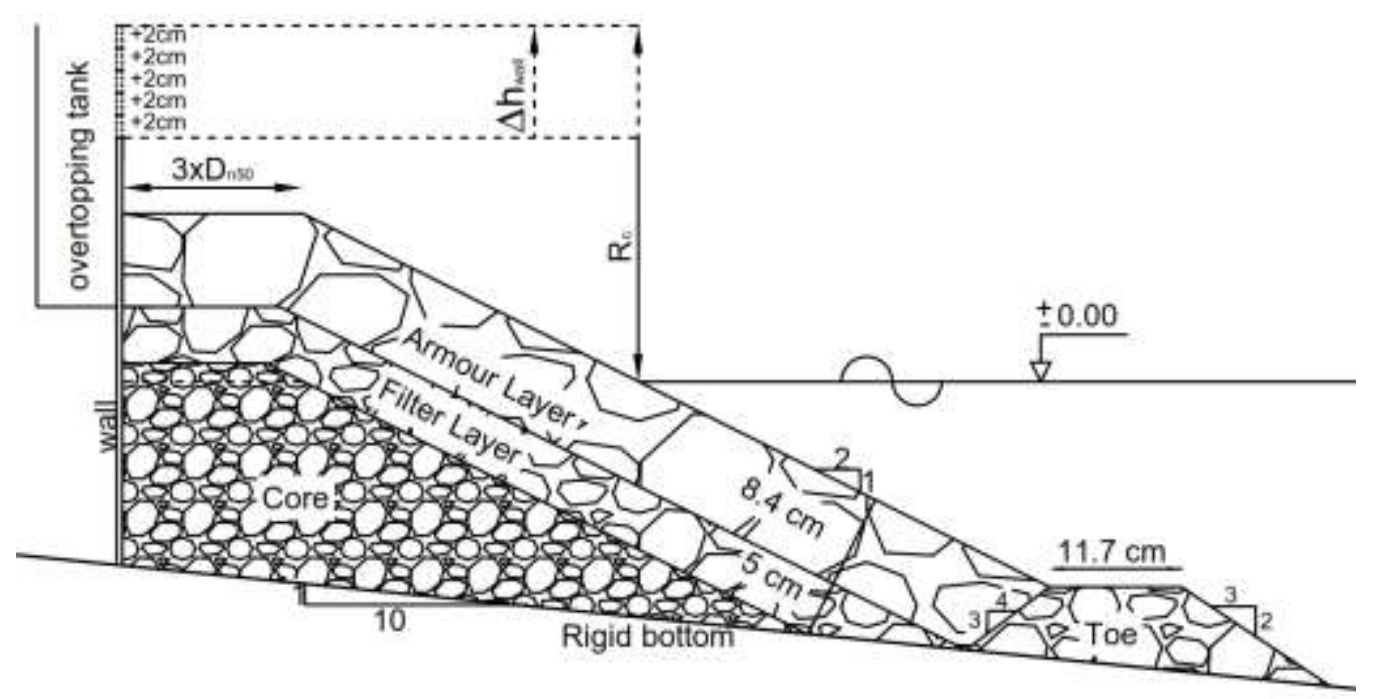

a) Schematic view of the composite seawall model
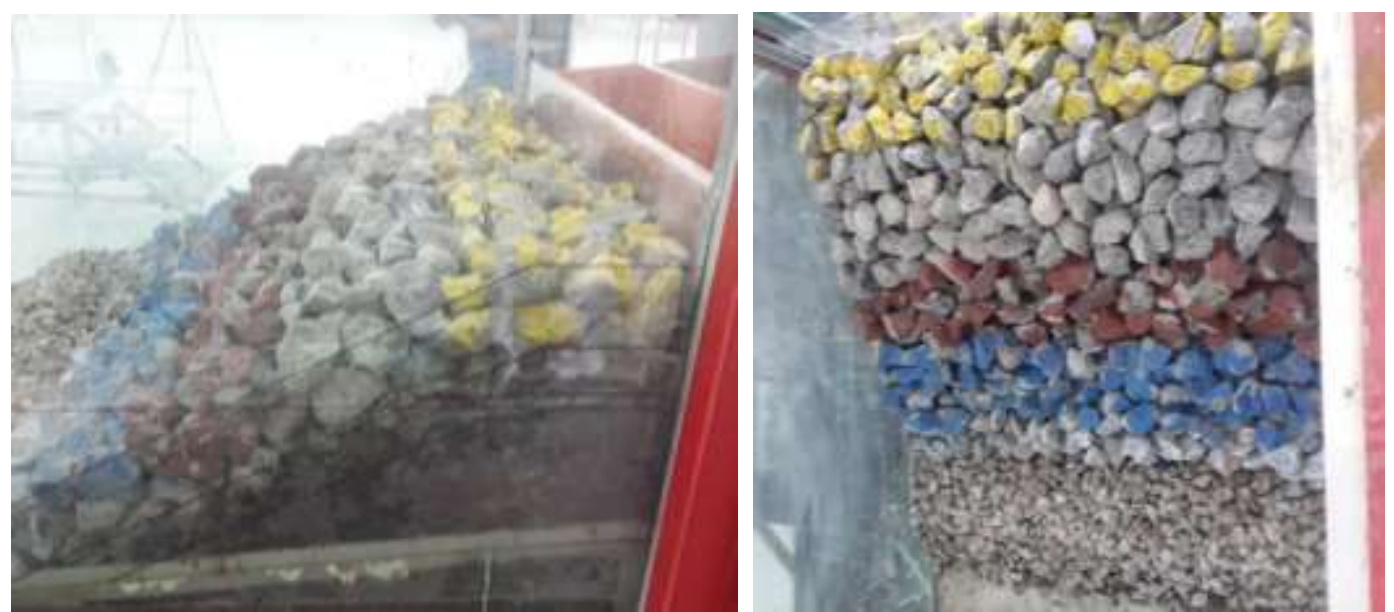

b) Photos of the composite seawall model

Figure 2 Cross-section of a composite seawall model

The rubble mound reclamation model was placed on a 1/10 bottom. 1/10 sloping fixed-bed bathymetry was constructed on a steel ramp.

Rubble mound reclamation model used in the experiments consists of three layers; an armor layer, a filter layer and a core. It was placed $24 \mathrm{~m}$ away from the wave generator. The slope angle with $\cot \alpha=2$ was used in the model. The thickness of armor layer was $8.4 \mathrm{~cm}$. Median mass $\left(\mathrm{M}_{50}\right)$ of the armor stone was 195 gr. Median mass of the stone at the filter layer $\left(\mathbf{M}_{50}\right)$ was $20.4 \mathrm{~g}$. Core material grading was in between $0.25-0.72 \mathrm{~cm}$. Porosity of the model was obtained as $37 \%$ for all tests in the armor layer.

Model stone armor units were obtained from a quarry. The grain size distributions of armor layer and filter were shown in Figure 3. This was achieved by weighing of individual stones. First, the core material and filter were placed. Then the armor units were placed by hand with the random placement method to simulate the prototype. 


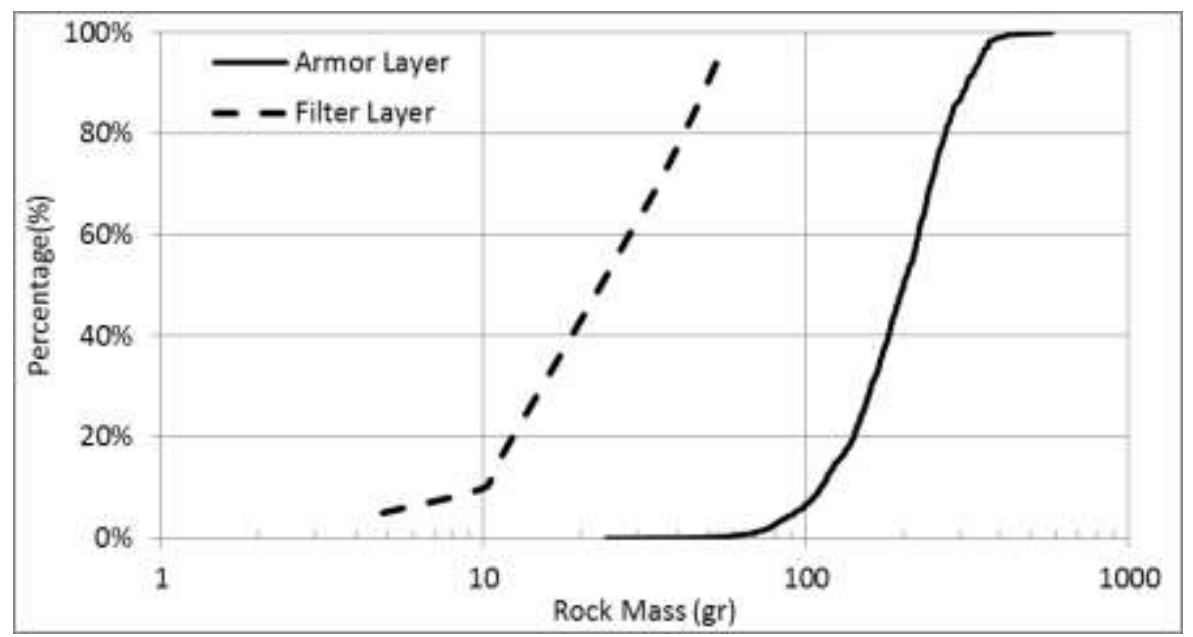

Figure 3 Grain size distribution curves for armor and filter layers

During the tests no significant damage was observed and the largest damage was identified as smaller than initial damage $\left(S_{d}=2\right)$.

\section{RESULTS and DISCUSSION}

The cross-section shown in Figure 2a was considered as a reference structure to study the effect of crest modifications (different crest elevations). As it can be seen from the figure the reference system already has a vertical wall at the crest of the rubble mound. Hence only the influences of the higher wall crest elevations $(+2 \mathrm{~cm},+4 \mathrm{~cm},+6 \mathrm{~cm},+8 \mathrm{~cm}$, and $+10 \mathrm{~cm})$ were evaluated with respect to the reference system. The most important difference of investigated structure from the structure existing in literature is the impermeable vertical wall behind the rubble mound section. First of all we evaluated the effect of this impermeable wall on the roughness of the structure. In Figure 4 all data were evaluated together. And the trendline of the new data set shows a good match to the EurOtop (2007) formula which is shown in Equation 1.

$$
\frac{q}{\sqrt{g \cdot H_{m 0}^{3}}}=0.2 \cdot \exp \left(-2.6 \frac{R_{c}}{H_{m 0} \cdot \gamma_{f} \cdot \gamma_{\beta}}\right)
$$

Where $\gamma_{\beta}$ is influence factor for oblique wave attack and $\gamma_{\beta}=1$ since to the perpendicular wave attack was considered in this study. $\gamma_{\mathrm{f}}$ is the roughness factor and it is taken as $\gamma_{\mathrm{f}}=0.55$ for rubble mounds with two layers and an impermeable core as suggested by EurOtop (2007). The line of EurOtop (2007) formula based on the $\gamma_{\mathrm{f}}=0.40$ (corresponds the rubble mound with 2 layers and a permeable core) and $\gamma_{\mathrm{f}}=1$ (a smooth dike slope) are also shown in the graph. Figure 4 clearly shows that this kind of structures as studied in this paper must be evaluated as a rubble mound with 2 layers and an impermeable core. According to Figure 4 wave steepness and wave period do not have an effect on mean overtopping discharge rates. 


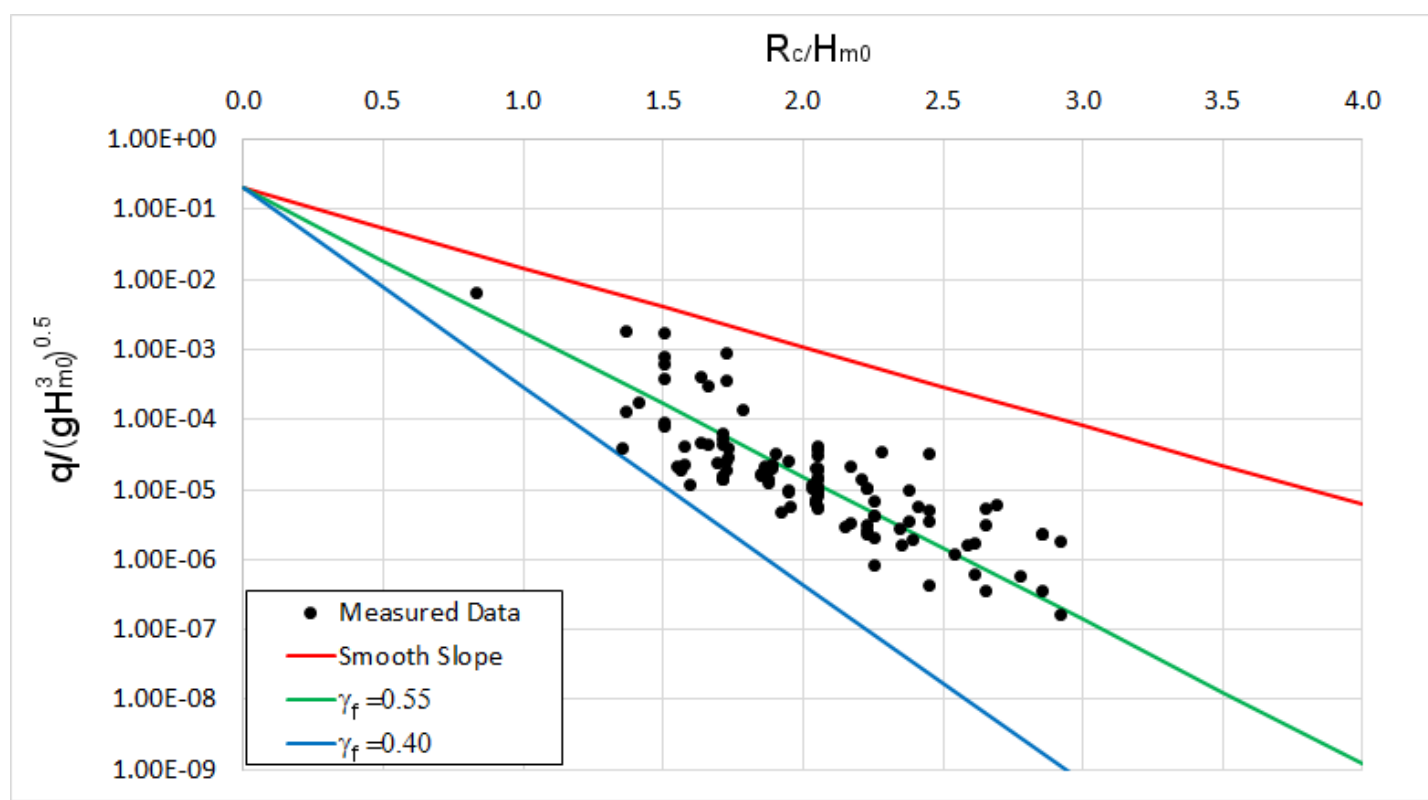

Figure 4 Measured mean overtopping discharges and the comparison with the EurOtop (2007) formula for all tests.

In EurOtop II (2016) a new equation has been proposed as given in Equation 2.

$$
\frac{q}{\sqrt{g \cdot H_{m 0}^{3}}}=0.09 \cdot \exp \left[-\left(1.5 \frac{R_{c}}{H_{m 0} \cdot \gamma_{f} \cdot \gamma_{\beta}}\right)^{1.3}\right]
$$

Test data collected in this study has also been compared to Equation 2 in Figure 5. Comparisons show that the data fits quite well to the new formula as well. New equation gives a new approach for low and high values of $\mathrm{R}_{\mathrm{c}} / \mathrm{H}_{\mathrm{m} 0}$. For the data range of this study both equations were well matched. Determination coefficients $\left(\mathrm{R}^{2}\right)$ of measured data to the EurOtop (2007) and measured data to EurOtop (2016) formulas have been calculated as 0.66 and 0.67 , respectively.

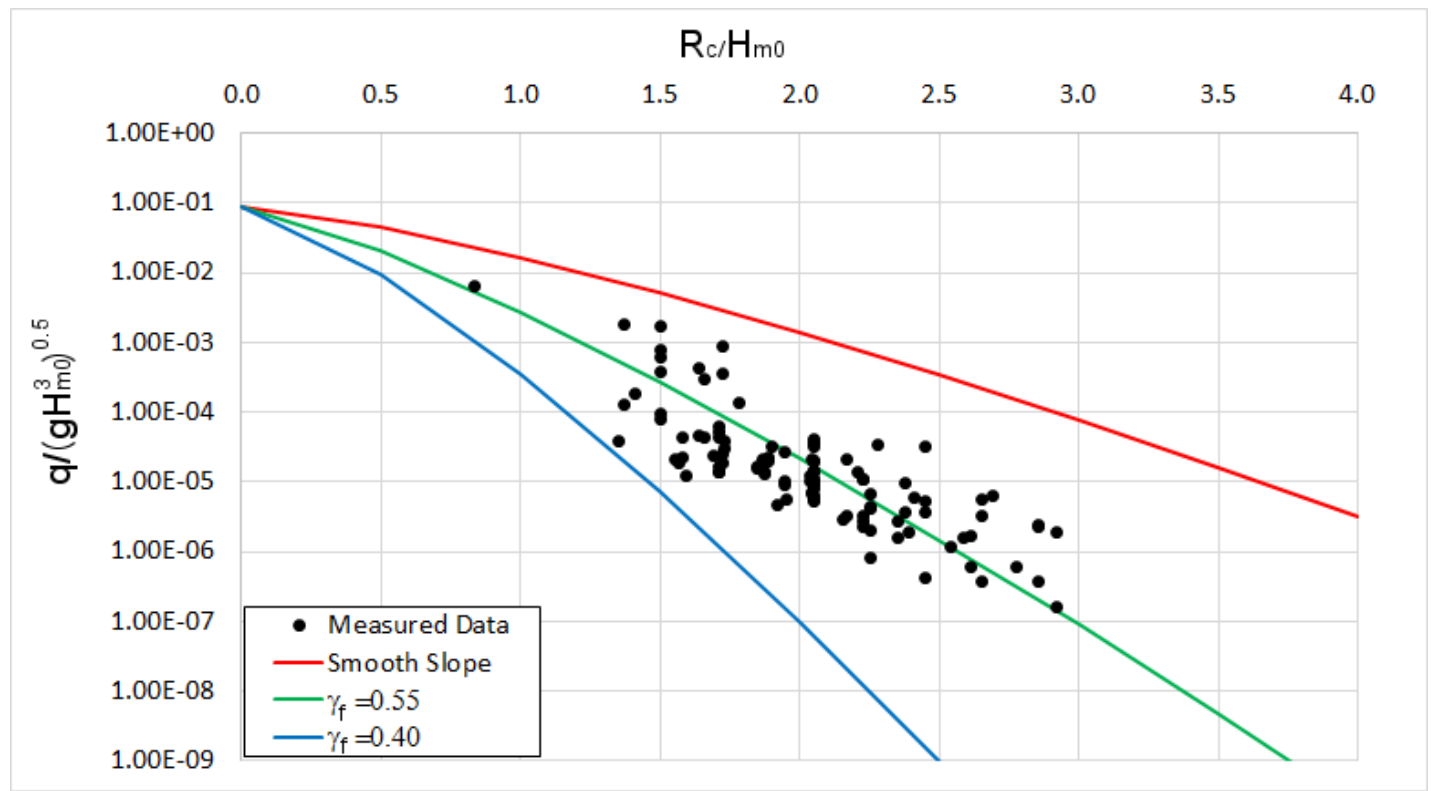

Figure 5 Measured mean overtopping discharges and the comparison with the EurOtop II (2016) formula. 
No suggestion or equation is given in EurOtop II (2016) for a storm wall with higher crest elevation than the rubble mound crest elevation. In this study, it is aimed to propose a reduction factor for the storm wall crest elevation. Initial storm wall crest elevation has been raised by $\Delta \mathrm{h}_{\text {wall }}=2 \mathrm{~cm}, 4 \mathrm{~cm}, 6 \mathrm{~cm}, 8 \mathrm{~cm}$ and $10 \mathrm{~cm}$, in sequence. Increasing the crest elevation changed the $R_{c}$ values accordingly. Normalized Overtopping Discharge Reduction Factor-NODRF ( $\left.\mathrm{q}_{\mathrm{q}} \mathrm{q}_{0}\right)$ were calculated, where $\mathrm{q}$ is the corresponding wave overtopping rate for increased wall height $\left(\Delta \mathrm{h}_{\text {wall }}=2 \mathrm{~cm}, 4 \mathrm{~cm}, 6 \mathrm{~cm}, 8 \mathrm{~cm}\right.$ or $\left.10 \mathrm{~cm}\right)$ and $\mathrm{q}_{0}$ is the wave overtopping rate for the reference system's crest elevation $\left(\Delta \mathrm{h}_{\text {wall }}=0\right)$. Test data has been evaluated by plotting the Normalized Crest Height Change-NCHC $\left(\Delta \mathrm{h}_{\text {wall }} / \mathrm{R}_{\mathrm{c}}\right)$ against $\operatorname{NODRF}\left(\mathrm{q} / \mathrm{q}_{0}\right)$. Evaluation of the results showed that the distinction among data must be made based on the wave steepness. Generally wave steepness of $\mathrm{s}_{0}=0.01$ corresponds a swell sea, while $\mathrm{s}_{0}>0.04$ indicates a wind sea. In Figure $6 \mathrm{NCHC}$ $\left(\Delta \mathrm{h}_{\text {wall }} / \mathrm{R}_{\mathrm{c}}\right)$ against $\operatorname{NODRF}\left(\mathrm{q} / \mathrm{q}_{0}\right)$ were shown for wind sea data where $\mathrm{s}_{0}>0.04$. NCHC in between 0.08 and 0.58 were applied during the tests. Our data has a maximum wave steepness of 0.057 . Swell sea state data with a wave steepness of $\mathrm{s}_{0} \approx 0.01$ was shown in Figure 7 and the transition waves between wind and swell were plotted in Figure 8.

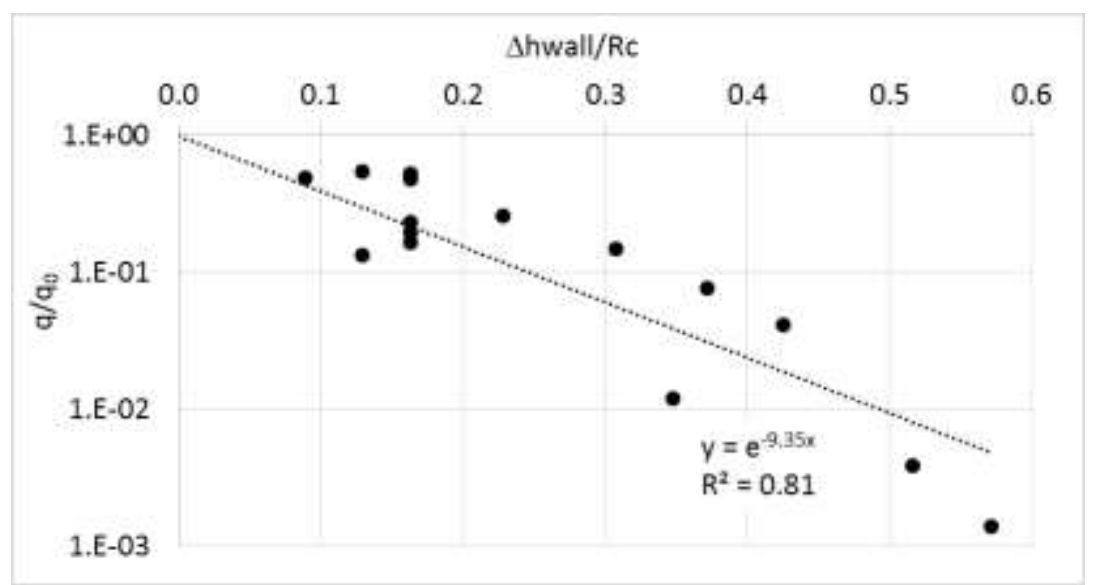

Figure 6 Reduction of wave overtopping due to normalized crest height change for wind waves $\left(s_{0}>0.04\right)$

$\operatorname{NODRF}\left(\mathrm{q} / \mathrm{q}_{0}\right)$ showed an exponential relation with the NCHC $\left(\Delta \mathrm{h}_{\text {wall }} / \mathrm{R}_{\mathrm{c}}\right)$ for all sea states. Results showed a good fit with $\mathrm{R}^{2}=0.81,0.73,0.65$ for wind waves, transition and swell sea states, respectively. Figures 6 to 8 show that increasing NCHC results a decrease in NODRF. Figures also show that this discharge reduction factor is also dependent on the wave steepness. Relation gradient of NODRF with NCHC was found to be much steeper for swell waves and milder in transition and wind wave conditions. This means increasing crest height of the wall has a higher impact on swell waves in terms of overtopping discharge reduction. 


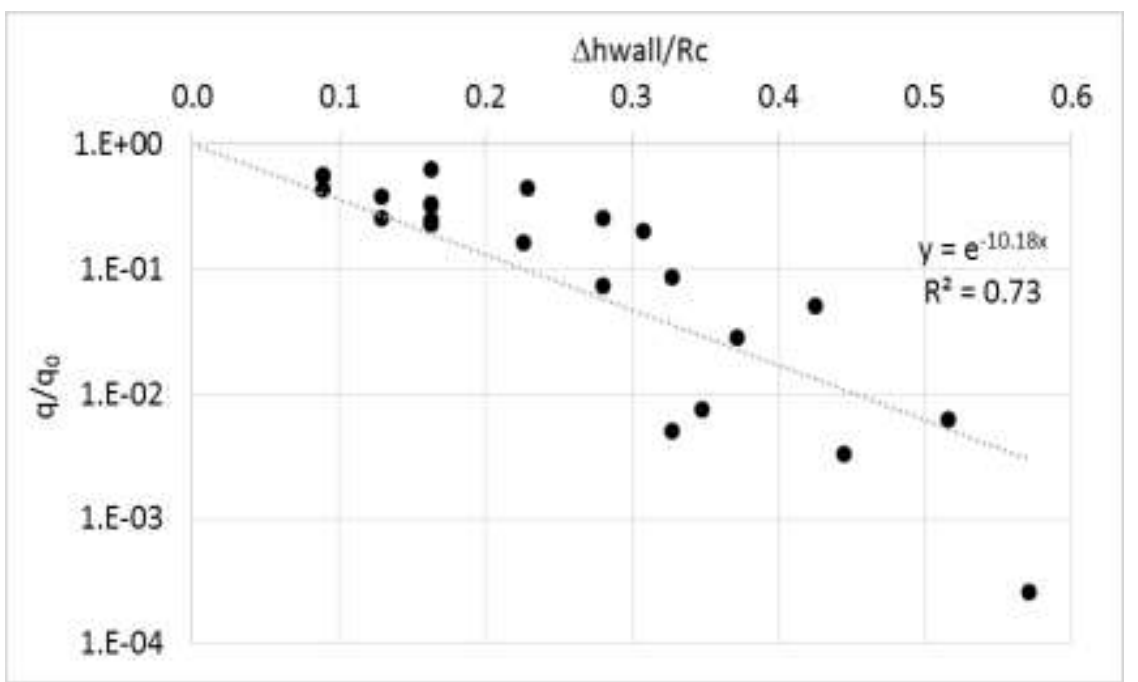

Figure 7 Reduction of wave overtopping due to normalized crest height change for $0.01<s_{0}<0.04$

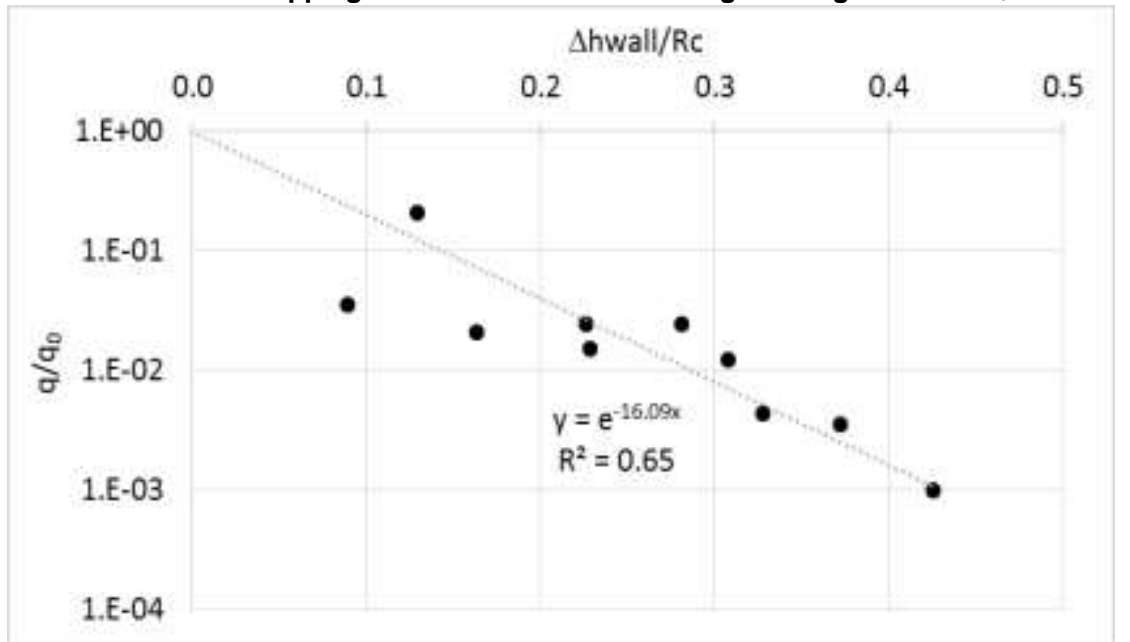

Figure 8 Reduction of wave overtopping due to normalized crest height change for swell waves $\left(s_{0} \sim 0.01\right)$

\section{CONCLUSIONS}

Extensive testing of a composite seawall has been conducted in a 2D wave flume, with nonbreaking waves, where the effects of different wall heights over the mean overtopping discharges were investigated. Some important conclusions from this study are summarized as follows:

1. A new type of composite seawall structure which is a rubble mound section with an impermeable vertical wall behind it, is tested in this study. Results showed that both EurOtop (2007) and EurOtop II (2016) formulas for composite seawalls are applicable to our test setup of this study with a roughness coefficient of 0.55 which corresponds to a rubble mound composite structure with two layers and an impermeable core. Vertical wall caused the composite structure act as if it is an impermeable structure.

2. EurOtop (2016) formula matched slightly better $\left(R^{2}=0.67\right)$ to the measured wave overtopping data in this study.

3. Height of the storm wall was raised 2, 4, 6, 8, and $10 \mathrm{~cm}$ successively for each wave condition. Results showed that a reduction rate clearly depends on the wave steepness. Raising crest elevation gave higher reductions of the mean overtopping discharges for the swell waves with smaller wave steepness.

4. In this study the reductive influence of the storm wall crest height on the mean wave overtopping rates was studied by raising the initial crest elevation of the existent storm wall. Test data has not 
been compared the structure without the storm wall. Storm wall effect should be studied by comparing the cross sections with and without storm wall in further studies.

\section{ACKNOWLEDGMENT}

This research was supported by the Yildiz Technical University through Research Grant No:2014-05-01-GEP01.

\section{REFERENCES}

Allsop, W., Bruce T., Pearson, J., and Besley, P. 2005. Wave overtopping at vertical and steep seawalls, Proceedings of the Institution of Civil Engineers Maritime Engineering, 158, 103-114.

De Rouck, J., Verhaeghe, H., Geeraerts, J. 2009. Crest level assessment of coastal structures General overview, Coastal Engineering, 56, 99-107.

EurOtop, (2007). Wave overtopping of sea defences and related structures: Assessment Manual. www.overtopping-manual.com.

EurOtop, (2016). Manual on wave overtopping of sea defences and related structures: Assessment Manual. www.overtopping-manual.com.

TAW. 2002. Technical Report. Wave runup and wave overtopping at dikes. Technical Advisory Committee on Flood Defence, Delft.

Troch, P., Mollaert, J., Peelman, S., Victor, L., Van der Meer, J., Gallach-Sánchez, D., and Kortenhaus A. 2014. Experimental study of overtopping performance for the case of very steep slopes and vertical walls with very small freeboards. Proceedings of $14^{\text {th }}$ International Conference on Coastal Engineering, ASCE, 1-8.

Van der Meer, J.W., and Bruce, T. 2014. New physical insight and design formulas on wave overtopping at sloping and vertical structures, Journal of Waterway, Port, Coastal, and Ocean Engineering, 140(6), Article 04014025.

Van der Meer, J.W., Janssen, J.P.F.M. 1994. Wave run-up and wave overtopping at dikes. ASCE. In: Wave Forces on Inclined and Vertical Wall Structures, Kobayashi, N., Demirbilek, Z. (Eds.), 1-27.

Van Doorslaer, K., De Rouck, J., Audenaert, S., and Duquet, V. 2015. Crest modifications to reduce wave overtopping of non-breaking waves over a smooth dike slope, Coastal Engineering, 101, 69-88.

Van Gent, M.R.A., Van Den Boogaard, H.F.P., Pozueta, B., Medina, J.R. 2007. Neural network modelling of wave overtopping at coastal structures, Coastal Engineering, 54, 586-593.

Verhaeghe, H., De Rouck, J., Van der Meer, J.. 2008. Combined classifier-quantifier model: a 2-phases neural model for prediction of wave overtopping at coastal structures. Coastal Engineering, 55 (5), $357-374$. 